\title{
A májtranszplantáció új kihívásai
}

\author{
Wettstein Dániel dr. ${ }^{1}$. Tóth Szabolcs József oh. ${ }^{2}$ - Máthé Zoltán dr. ${ }^{3^{*}}$ \\ ${ }^{1}$ Országos Onkológiai Intézet, Daganatsebészeti Centrum, Budapest \\ ${ }^{2}$ Semmelweis Egyetem, Általános Orvostudományi Kar, Budapest \\ ${ }^{3}$ Semmelweis Egyetem, Általános Orvostudományi Kar, Transzplantációs és Sebészeti Klinika, Budapest
}

\begin{abstract}
A májtranszplantáció eredményei az elmúlt évtizedekben jelentősen javultak. Egyre több beteg számára jelent életmentő kezelést a májátültetés, miközben az indikációk köre is változik. A világszerte fennálló szervhiány azonban új stratégiák kidolgozására készteti a szakmát. A donorkritériumok észszerű kiterjesztésével, precízebb szervallokációval, személyre szabott donációval, élődonációval, gépi perfúzió alkalmazásával és a szívmegállást követő donáció bevezetésével új távlatok nyílnak, amelyek eredményeként a májtranszplantáció egyre több végstádiumú májbeteg számára válhat elérhetővé. Összefoglaló közleményünkben az új lehetőségeket és kihívásokat mutatjuk be a magyarországi májtranszplantációs program tükrében.
\end{abstract}

Orv Hetil. 2019; 160(29): 1127-1135.

Kulcsszavak: májtranszplantáció, kiterjesztett donorkritériumok, élődonoros májtranszplantáció, gépi perfúzió

\section{New challenges of liver transplantation}

In the last decades, the results of liver transplantation have shown significant improvement. More patients are eligible for liver transplantation, while the indications are changing. The worldwide shortage of donor organs urges the profession for the development of new strategies. With rational extension of donor criteria, more precise organ allocation, personalized donation, living related donation, machine perfusion, and donation after cardiac death, liver transplantation is becoming available for more and more patients suffering from end stage liver disease. Hereby we summarize the new possibilities and challenges in the light of the Hungarian liver transplant program.

Keywords: liver transplantation, extended criteria donation, living donor liver transplantation, machine perfusion

Wettstein D, Tóth SzJ, Máthé Z. [New challenges of liver transplantation]. Orv Hetil. 2019; 160(29): 1127-1135.

(Beérkezett: 2019. február 28.; elfogadva: 2019. március 21.)

\section{Rövidítések}

ALAT = alanin-aminotranszferáz; ASAT = aszpartát-aminotranszferáz; $\mathrm{BMI}=($ body mass index $)$ testtömegindex; CIT $=$ (cold ischemic time) hidegischaemiás idő; $\mathrm{CT}=$ (computed tomography) számítógépes tomográfia; $\mathrm{DAA}=($ direct acting antiviral) direkt hatású antivirális szer; $\mathrm{DBD}=($ donation after brain death $)$ agyhalált követő donáció; $\mathrm{DCD}=($ donation after cardiac death) szívmegállást követő donáció; DRI $=$ (donor risk index $)$ donorrizikó-index; EAD = (early allograft dysfunction) korai allograftdiszfunkció; ECD $=($ extended criteria donation) kiterjesztett kritériumú donáció; FLR = (future liver remnant) megmaradó májszövet; GGT = gamma-glutamiltranszferáz; $\mathrm{HBV}=$ hepatitis $\mathrm{B}$-vírus; $\mathrm{HCC}=($ hepatocellular carcinoma) hepatocellularis carcinoma; $\mathrm{HCV}=$ hepatitis $\mathrm{C}$-vírus; $\mathrm{IPF}=$ (initial poor function) kezdeti graftdiszfunkció; IRI $=($ ischemia-reperfusion injury) ischaemia-reperfúziós károso- dás; $\mathrm{MELD}=($ Model for End-Stage Liver Disease $)$ végstádiumú májbetegségek matematikai modellje; $\mathrm{MRCP}=$ mágneses rezonanciás kolangiopankreatográfia; $\mathrm{mTOR}=($ mammalian target of rapamycin) a rapamicin célpontja emlösökben; NASH $=$ (non-alcoholic steatohepatitis) nem alkoholos eredetü steatohepatitis; PNF $=$ (primary non function) primer múködésképtelenség; $\mathrm{UH}=$ ultrahangvizsgálat

A modern májtranszplantáció időszámításának kezdete - az egyéb allogén transzplantációkhoz hasonlóan - az immunszuppresszió megjelenésére tehető. Mintegy 20 évvel a világelső Thomas Earl Starzl után végezte el az első technikailag sikeres májátültetést Szécsény Andor 1983-ban Budapesten, azonban a korlátozott immun-

*Jelenlegi munkahely: Medizinische Universität Graz, Universitätsklinik für Chirurgie, Klinische Abteilung für Transplantationschirurgie 
szuppresszív terápiás lehetőségek birtokában a beteg túlélése csupán 3 hónap volt. Hosszú szünet után, 1995ben indult el Magyarországon a Transzplantációs és Sebészeti Klinikán a májtranszplantációs program Perner Ferenc vezetésével. Ettől kezdve évről évre nőtt a májátültetések száma, 2014-től az aktivitás a kétszeresére emelkedett. Ezt követően az Eurotransplant-centrumok között már az első ötben szerepel a Transzplantációs és Sebészeti Klinika az évi 75-89 májátültetéssel. Az elmúlt negyed évszázadban a májtranszplantáció komoly fejlődésen ment keresztül, amíg a mai, igen biztató eredményeket elértük a májtranszplantációt követő túlélés és életminőség terén. Napjainkban a legfontosabb cél továbbra is a magas szakmai színvonal biztosítása és az esély megteremtése a szervátültetésre úgy, hogy az Eurotransplant adatai alapján az elérhető donorok száma évek óta minimálisan változik, miközben a várólistán egyre több beteg vár új szervre. A várólista-mortalitás 8-15\% közötti, a mütétre kerülő betegek állapota romlik, a 25 feletti MELD- (Model for End-Stage Liver Disease) pontszámú betegek aránya az Eurotransplant adatai alapján a 10\%-ot is meghaladja $[1,2]$. A májtranszplantáció által nyújtott életmentő kezelést így csak bizonyos, észszerü kompromisszumok árán tehetjük még szélesebb körben elérhetővé.

\section{A donor, a recipiens és a mütét}

A májtranszplantáció korai eredményeit leginkább a donor, a recipiens és a mútét egyes tényezői határozzák meg.

A májtranszplantációt követő korai allograftdiszfunkció (EAD), ezen belül a primer múködésképtelenség (PNF), valamint a kezdeti graftdiszfunkció (IPF), illetve a korai vascularis és epeúti szövődmények a hosszú távú graft- és recipienstúlélést meghatározó legfontosabb tényezők [3]. Ezek predikciójára számos stratégiát dolgoztak ki, melyek célja a transzplantációk számának növelése a szövődmények alacsony szinten tartásával [4]. A határok tágításával bizonyos mértékű kockázatnövekedés elkerülhetetlen, ezért a posztoperatív graftmúködés szoros követése kiemelkedő jelentőséggel bír a PNF és az IPF elkülönítésében, a megfelelő multimodális kezelés és szükség esetén a korai retranszplantáció indikációjának felállításában [5].

\section{A donor-kiterjesztett donorkritériumok (extended criteria donation, ECD) alkalmazása}

A donorrizikó-index (DRI) koncepcióját kidolgozó Feng és mtsai szerint az ideális donor 40 évesnél fiatalabb, traumás halálokkal, agyhalál utáni donációval, hemodinamikailag stabil állapotban, steatosis, illetve egyéb májbetegség, valamint átvihető betegség nélkül [6]. A donorok nagy része azonban nem tartozik az ideális csoportba, ezért a szervhiány enyhítésére a régi dogmák átértékelésével olyan új stratégiákat kellett kidolgozni, melyek a transzplantációk számának növelését szolgálják a minőség romlása nélkül, 80-90\% feletti egyéves betegtúléléssel [7]. Ezt a törekvést szolgálja a donorkritériumok észszerü, körültekintő kiterjesztése, ami mára világszerte megfigyelhető tendencia. A kiterjesztett kritériumoknak megfelelő donorok számának növekedése jelentős, arányuk mára 60\% fölé tehető, a magas DRI-vel rendelkező donorok arányának növekedése pedig meghaladja a $23 \%$ ot [2]. A donor minősége egy kontinuum mentén helyezkedik el; kiterjesztett kritériumokról mesterséges definíció szerint beszélhetünk a következők alapján: életkor $(\geq 60)$, BMI $\left(>27-30 \mathrm{~kg} / \mathrm{m}^{2}\right)$, macrovesicularis steatosis ( $\geq 30 \%)$, az intenzív osztályos kezelés időtartama (4-5 nap), vazoaktív szerek használata, hipotenzív periódus (>1 óra), szérumnátriumszint (>150-155 mmol/l), hideg- és melegischaemiás idő (>8 óra, illetve $>1$ óra), kontrollált szepszis, vesefunkció (szérumkreatinin-szint $>106 \mu \mathrm{mol} / \mathrm{l})$, alkoholos anamnézis, szérumbilirubin(>34,2 $\mathrm{\mu mol} / \mathrm{l}$ ) és -transzamináz-szintek (ALT>170 $\mathrm{IU} / 1, \mathrm{AST}>140 \mathrm{IU} / 1)[8]$.

\section{A recipiens}

A recipiensek állapotát legpontosabban leíró MELDpontszám egyben a transzplantációt követő morbiditás és mortalitás prediktoraként is szolgálhat [9]. A magasabb pontszámból, avagy a súlyosabb betegségből következő mortalitás csökkentésének egyik eszköze lehet az ECD-donorok alkalmazása megfelelő kautélák mellett, így a várakozási idő rövidíthető [5]. A kiterjesztett kritériumokkal elfogadott graftok allokációja továbbra is megoldatlan problémát jelent. Egyes közlemények szerint a magas recipiens-MELD-pontszám és magas DRIpontszámok között nincs számottevő interakció, így az ECD-donorok biztonságosan használhatók a súlyosabb betegek körében is [10], míg más közlemények szerint a komplikációk, valamint HCV miatt transzplantált betegek esetében a HCV-rekurrencia magasabb aránya miatt ez a gyakorlat kerülendő [11]. A kiterjesztett kritériumok alapján elfogadott szervek jól múködhetnek alacsonyabb MELD-pontszámú, például tumoros betegekben, akiknél a várakozási idővel párhuzamosan a tumor (például HCC) extrahepaticus terjedése várható, a korai transzplantációval viszont esélyt kaphatnak a kuratív kezelésre. Az aacheni munkacsoport 50, HCC-indikációval transzplantált beteg retrospektív vizsgálatával arra a következtetésre jutott, hogy az ECD- és standard donorkritériumokkal történt transzplantációk hosszú távú kimenetelében nincs szignifikáns különbség [12].

\section{A szervkivétel és-beültetés}

Fontos eleme a rizikócsökkentésnek a donáció közben és azt követően fellépő komplikációk minimalizálása. Ilyen a hosszú hidegischaemiás idő (CIT), illetve a nem felis- 
mert anatómiai variációk. A kiterjesztett donorkritériumok alkalmazása esetén különösen fontos a hidegischaemiás idő minimalizálása: a standard donorkritériumok esetén nemzetközileg elfogadott 10-12 óra helyett a CIT 8 óra alatt tartása javasolt [13].

A máj beültetésekor módosítható kockázati tényezők közül Bolondi és mtsai szerint az alábbiak kimenetelt befolyásoló szerepe szignifikáns: a beavatkozás hossza, a nehéz artériás anasztomózis, nagyfokú vérveszteség és transzfúzióigény, az intraoperatív hemodinamikai instabilitás, a hideg- és melegischaemiás idő, az ischaemiareperfúziós károsodás (IRI), a sebészi revízió szükségessége és azok száma [8].

\section{Kockázati tényezők az ECD-májtranszplantációk során}

\section{Graftsteatosis és fibrosis}

A kiterjesztett kritériumok alkalmazásával bizonyos mértékû steatosis a graftmájban elfogadható. A steatosis hetekkel a transzplantációt követően visszafejlődhet, azonban a korai funkcionális regeneráció ezekben az esetekben károsodott, mivel a steatosis ischaemia-reperfúziós károsodásokra fogékonnyá teszi a graftot [14]. Zsírmáj esetében ugyanis a kitágult hepatocyták komprimálják a sinusoidok lumenét, ezáltal növelik a portalis rezisztenciát. Ez magyarázza az inverz korrelációt a steatosis mértéke és a sinusok véráramlása között. A fenti mechanizmus a hidegperfúzió hatásfokát rontja, valamint reperfúzió után relatív hypoxiát okoz [15]. A májban hisztopatológiai morfológia alapján megkülönböztetünk microvesicularis és macrovesicularis steatosist a hepatocytákban található zsírvacuolumok méretétől függően. A microvesicularis steatosis nem befolyásolja jelentősen a transzplantáció kimenetelét. A hepatocyták kevesebb mint 30\%-át érintő macrovesicularis steatosis nem jár érdemi rizikónövekedéssel, 30-60\% között azonban csak nagy körültekintéssel (személyre szabottan, alacsony CIT, sürgető transzplantáció), $60 \%$ felett pedig egyáltalán nem alkalmas a máj transzplantációra $[16,17]$. A steatosis mértéke objektíven csak biopsziával állapítható meg, tapasztalt májpatológus bevonásával. Ezt alátámasztják saját biopsziás adataink, melyek szerint az inspekció alapján steatosis miatt elutasított graftok egyharmada 30\%nál kevesebb macrovesicularis zsírt tartalmazott az utólagos szövettani feldolgozás során. Fibrosis jelenléte a steatosis mértékétől függetlenül kontraindikációt jelent a transzplantációra.

\section{A donor életkora}

A donorok magas életkora nem jelent abszolút kontraindikációt a májdonációra, az idősebb donorokból származó graftok esetén azonban számolni kell a regeneratív kapacitás romlásával és a hepatitis C-fertőzés rekurrenciája esetén fulmináns lefolyással is [18]. A transzplantáció hajnalán az 50 évesnél idősebb donorok nem jöttek számításba, azonban az Eurotransplant-régióban az 1990. évi 35 éves medián donoréletkor 2016-ra 54 évre növekedett, és 2015-ben Németországban már $30 \%$ feletti volt a 65 évesnél idősebb májdonorok aránya $[2,19]$. A 75 év feletti donormájak is transzplantálhatók megfelelő feltételek mellett, de csak jól szelektált betegek esetén múködnek elfogadható eredménnyel [20]. Alacsony MELD-pontszámú, HCC (hepatocellularis carcinoma) miatt transzplantált, illetve HCV-negatív betegek megfelelő donor-recipiens párosítás esetén profitálhatnak az idős májgraftokkal történő transzplantációból is $[5,21]$.

\section{A donor emelkedett májenzimei}

Nem jelent abszolút kontraindikációt májdonációra a szérumtranszaminázok magas szintje, ahogy azok a normáltartományban sem zárják ki a parenchymakárosodás lehetőségét. A szérumtranszaminázok értékelése a donorgondozás során megfigyelhető tendenciákkal és egyéb donorparaméterekkel együtt része a döntéshozatalnak. Az emelkedett epeúti enzimek, így a 200 IU/1 feletti GGT nagyobb jelentőséggel bír, de ebben az esetben is további vizsgálatokra van szükség. A máj alkalmasságáról az UH-vizsgálat, az anamnesztikus adatok és a biopszia együttes értékelése alapján születhet döntés [22]. Megfelelő, alacsony kockázatú recipiensek (MELD<25, HCC) kiválasztása esetén $85 \%$ feletti egyéves grafttúlélés érhető el a donor markánsan emelkedett májenzimei mellett történő májtranszplantációk esetében is [23].

\section{Graft által átviheto" betegségek}

A donor fertőző betegsége nem abszolút kizáró ok a transzplantációra. A donor HBV- és HCV-fertőzöttsége, valamint igazolt korábbi fertőzés esetén azonos betegségben szenvedő recipiens kaphat szervet a víruspozitív donortól az Eurotransplant számos országában, így Magyarországon is, speciális kezelési szempontok figyelembevételével [24].

A hepatitis B-core-ellenes antitestre ( $\mathrm{HBcAb}-)$ pozitív donormájak krónikus hepatitis B-fertőzésben szenvedő recipiensek számára jó eredményekkel beültethetők, transzplantációt követő $\mathrm{HBV}$-ellenes kezeléssel kiegészítve [25].

A legújabb, direkt ható antivirális szerek (DAA-k) hatásossága kiemelkedő, a HCV sikeresen eliminálható az esetek több mint 95\%-ában [26]. Kontraindikáció hiányában anti-HCV-pozitív donorból származó szolid szerv (beleértve a májat) a beteg felvilágosítása és írásos beleegyezése után anti-HCV-pozitív recipiensbe beültethető. A transzplantáció előtt biopszia és gyors szövettani vizsgálat szükséges a fibrosis kizárására. A májtranszplantációs várólistán lévő Child-Pugh $\mathrm{A}$ vagy $\mathrm{B}$ stádiumú, 
HCV-pozitív betegek antivirális kezelése indokolt, a májátültetés indikációjától függetlenül. Child-Pugh $\mathrm{C}$ stádiumban a HCV elleni kezelés időzítését illetően egyéni mérlegelés szükséges [27].

A DAA-k hatékonyságának köszönhetően, valamint a megfelelő graftok hiányából adódóan a HCV-viraemiás donorokból származó májak átültetése HCV-viraemiás recipiensekbe egyre szélesebb körben elterjedt módszer, adekvát transzplantáció utáni antivirális terápia alkalmazása mellett. Példaképp az Egyesült Államokban a fenti megfontolásoknak megfelelően a HCV-szeropozitív transzplantáció 10\%-os emelkedése volt megfigyelhető a 2010 és 2015 közötti periódusban, már az interferonmentes terápia megjelenésekor [28].

$\mathrm{Az}$ új DAA-k megjelenésével a $\mathrm{HCV}$ indikációjával transzplantált betegek száma már Magyarországon is lényegesen csökkent, és ebben további csökkenés várható. A DAA-k használata a következô évtizedben a májtranszplantáció nemzetközileg vezető indikációs körét alapjaiban változtathatja meg $[29,30]$.

Önmagában nem jelent kontraindikációt a donor izolált, kezelt bakteriális fertőzése sem, de a recipiens profilaktikus antibiotikumkezelése, szoros monitorozása a transzplantációt követően és infekciótranszmisszió gyanúja esetén korai célzott antimikrobás kezelése elengedhetetlen [31]. A donor malignus betegsége majdnem minden esetben transzplantációt kizáró ok. A donorok életkorának emelkedésével nő a malignitások gyakorisága is, ami nemzetközi adatok alapján a donorok 3\%-át érinti [32]. A 2008. évi párizsi konszenzuskonferencia ajánlása alapján a donor központi idegrendszerét érintő grade I-II. tumorok, illetve korai stádiumú vesesejtes daganatok esetén a donormáj felhasználható transzplantáció céljára, a recipiens azonban a későbbiekben körültekintő gondozást és az immunszuppresszív hatása mellett angiogenezisgátló hatással egyaránt bíró mTORinhibitor-alapú immunszuppresszív kezelést igényel [33].

\section{Parciális májgraft}

A redukált máj átültetésének ötlete nem új keletú, az első sikeres split, illetve élődonoros májátültetések óta közel 30 év telt el. A technikai fejlődés lehetővé tette a laparoszkópos élődonoros bisegmentectomiát 2002-ben, majd laparoszkópos élődonoros jobb hemihepatectomiáról is beszámoltak 2012-ben [34]. Budapesten 2007ben történt dokumentált felnőttkori élődonoros májtranszplantáció jobb májlebeny felhasználásával [35]. Gyermek élődonoros transzplantációt (2-3-as szegmentum) is végeztek korábban két esetben.

Élődonoros, valamint split májtranszplantáció esetén is csak akkor érhetők el a kadáver-májtranszplantációval összevethető eredmények, ha nagy volumenú, gyakorlott centrumban, gondosan szelektált beteganyagon végzik a mütéteket [36-38].

\section{Élődonoros májátülttetés}

Az élődonoros májtranszplantáció elsősorban olyan ázsiai régiókban terjedt el, ahol a kadáverdonáció vallási és kulturális okból háttérbe szorul. Tajvanban és Dél-Koreában a legmagasabb az élődonoros májtranszplantációk aránya egymillió före vonatkoztatva 16-17 élődonációval, míg az Amerikai Egyesült Államokban 2017-ben 1,1 élődonoros transzplantáció jutott egymillió főre [39, 40]. Európában nem következett be jelentős áttörés az élődonoros transzplantációk számának alakulásában: a 2017-ben végzett 7984 májátültetésból az elmúlt évekhez hasonlóan 3\% történt élő donorból, míg globálisan ez az arány eléri a 21\%-ot [41].

$\mathrm{Az}$ élődonoros májtranszplantáció nyitottan vagy - újabban egyes centrumokban - laparoszkópos módszerrel végzett májreszekciót jelent az egészséges donor számára, melynek során bal vagy jobb oldali hepatolobectomia történik a recipiens testméretétől függően. Előnye a kadáver donorból származó transzplantációhoz képest, hogy a várakozási idő és a várólista-mortalitás csökken, és sok esetben egyetlen reális esélyt jelent a gyógyulásra, amikor a hosszas várakozás fatális kimenetelû́ volna az alapbetegség progressziója miatt. Ez a lehetőség főleg a hepatocellularis carcinomában szenvedő betegek esetében lényeges, amikor a korai transzplantáció igen fontos a tumorpropagáció megelőzése szempontjából. Gyermek recipiensek esetén ideális testméretű donor ritkán adódik, ezért sok esetben az egyetlen lehetőség az élődonáció. Kis testtömegü recipiens számára a legtöbbször a bal oldali májlebeny donációja történik, ami a jobb lebeny donációjához képest alacsonyabb kockázattal jár. Az esseni munkacsoport tapasztalatai alapján bal lateralis májlebeny donációját követően a minor komplikációk előfordulása $3 \%$ körüli, a túlélés pedig $100 \%$ [42]. A donormütétet megelőzően a donor részletes kivizsgálásának sarkalatos pontja a képalkotó vizsgálatok elvégzése az ér- és epeúti variációk feltérképezése céljából (CT-angiográfia, MRCP, UH), és a mütét kezdetén intraoperatív kolangiográfia végzése is javasolt. A máj vérellátási variációi, illetve epeúti variációk jelentősen megnehezíthetik a donációt, bizonyos esetekben akár kontraindikációt jelenthetnek. A CT-volumetria segít a mütéti tervezésben, illetve a kockázatbecslésben, hiszen a donor reziduális májszövete (future liver remnant, FLR) ez alapján megbecsülhető. Mind a donor, mind a recipiens számára minimum a testtömeg $1 \%$-át kitevő ép májszövet szükséges a posztoperatív májelégtelenség elkerülése érdekében. Az ép májszövet rendkívül jó regenerációs készségének köszönhetően a máj várhatóan 4-6 héttel a mútét után visszanyeri eredeti méretét.

\section{Split májtranszplantáció}

A transzplantációk számának növelésére kiváló módszer a kadávermájak osztott transzplantációja, így egy megfelelő minőségű kadáver donorból származó máj két reci- 
piens számára ültethető be. Ebben az esetben a máj anatómiai szétválasztása történhet a donormütét során in situ, de a legtöbbször a beültetést megelőzően hidegen, a háttérasztalon történik. A kettéosztott máj bal lebenyei (S2-3, esetleg S4 is) legtöbbször gyermektranszplantációra, míg a jobb oldali lebenyek felnőtt-transzplantációra is alkalmasak [43]. A split májtranszplantációk az európai májtranszplantációk 5,2\%-át tették ki 2015-ben, országonként azonban jelentős eltérések figyelhetők meg, például az Egyesült Királyságban ez az arány 12,3\% volt [41].

\section{Szívmegállást követő donáció (DCD)}

A kadáver szervdonorok típusától függően megkülönböztetünk agyhalottból történő donációt (DBD, donation after brain death), illetve szívmegállást követő donációt (DCD, donation after cardiac death). Agyhalottból történő donáció során a neurológiai kritériumok alapján megállapított agyhalált követően a szervek vérátáramlása folyamatos, egészen a sebész által megkezdett hidegperfúzióig, hiszen dobogó szívű donoron kezdődik el a szervkivételi mútét. A DCD abban különbözik az agyhalál után történő donációtól, hogy a neurológiai agyhalál kritériumai nem teljesülnek, ezért a donáció és ezáltal a hidegperfúzió a keringésleállást követő, törvényileg előírt obszervációs időt követően kezdhető meg [44]. A DCD-donáció elterjedését mutatja, hogy az Egyesült Királyságban és Hollandiában a donorok 30-40\%-a tartozik ebbe a csoportba [45].

A DCD-donorokból származó májak transzplantációjának eredményei azonban egyes közlemények adatai alapján rosszabbak az agyhalott donorokból származó transzplantációk eredményeinél, amit a korai melegischaemiás periódussal magyaráznak [46]. A DBD- és DCD-donorokból származó graftok 1, 5 és 10 éves túlélését globálisan vizsgálva szignifikánsan rosszabb túlélési eredmények tapasztalhatók de Vera és mtsai szerint (82 vs. $69 \%, 73$ vs. $56 \%$ és 63 vs. 44\%) [47]. Megfelelő donor-recipiens párosítással, a hideg- és melegischaemiás

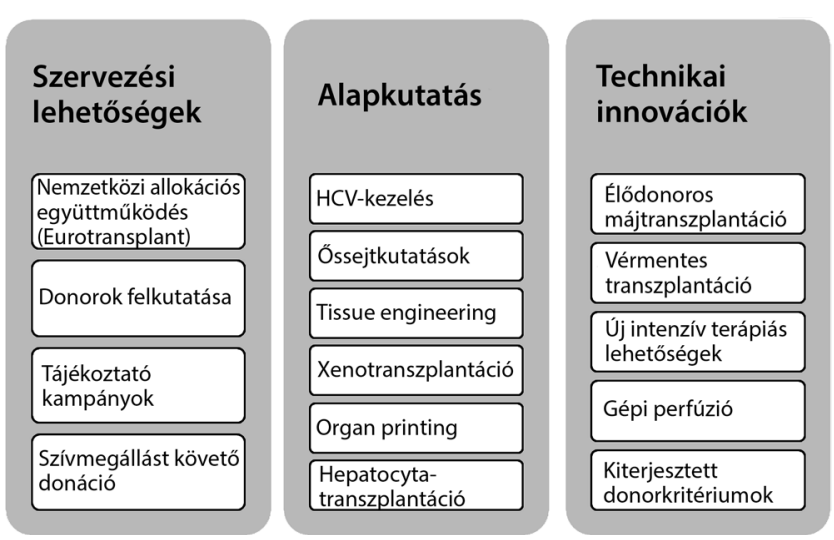

1. ábra A májtranszplantáció fejlődését elősegítő tényezők idő csökkentésével, valamint az idős donorok kerülésével a DBD-donorokhoz hasonlóan jó eredményeket kaptak Grewal és mtsai 108 DCD- és 1328 DBD-májgraft öszszehasonlításával, de az epeúti komplikációk aránya így is magasabb maradt $(8,3 \%$ vs. $1,9 \%)$ [48]. A melegischaemia következményének tekintik a gyakrabban előforduló, transzplantáció utáni primer múködésképtelenséget (PNF, primary non function) és az intrahepaticus epeúti strictura megjelenését is. A DCD-májtranszplantáció csak a recipiensek körültekintő kiválasztása esetén alkalmazható biztonságosan. Daganatos betegek, illetve magas MELD-pontszámú, kritikus állapotú betegek esetén a DCD-májak használata esetenként az egyetlen lehetséges gyógymódot jelentheti [49]. DCD-donáció jelenleg Magyarországon nem lehetséges.

\section{A májtranszplantáció fejlődését elősegítő tényezők (1. ábra)}

\section{Technikai innovációk a májtranszplantációban}

Az elmúlt évek sebésztechnikai újításai nagyban hozzájárultak a májtranszplantáció fejlődéséhez. Sebészi innováció tette lehetôvé az élődonoros, valamint a split májtranszplantációk sikeres kivitelezését.

\section{Vérmentes májtranszplantáció}

A transzfúziómentes transzplantációk kivitelezése az eredmények javulásához vezet, melyben a mikrosebészeti módszerek és az új technikai eszközök (ultrahangos vágókészülék, érvarró gépek) mellett a modern anesztézia és a haemostaseologia fejlődése is igen fontos szerepet játszik. A vérmentes technika és a mikrosebészeti megközelítés elónye a kisebb intraoperatív trauma, a rövidebb mútéti idő (3-5 óra), a gyorsabb extubáció és a rövidebb intenzív osztályos kezelés (1-2 nap). Ennek köszönhető a gyorsabb gyógyulás, mobilizálás és rehabilitáció, amit a sebészet más ágazataiban már korábban sikeresen alkalmazott „fast track” koncepcióként összegezhetünk [50]. A budapesti centrumban 2014 és 2018 között tanulmányozott 399 májtranszplantáció majdnem fele, $47 \%$ intraoperatív vörösvérsejt-készítmény adása nélkül volt kivitelezhető.

\section{Gépi perfúzió}

A modern szervkonzerváló oldatok megjelenéséig a donáció és a szerv beültetése közti ischaemiás időben bonyolult szerkezeteket alkalmaztak a graftkárosodások kivédésére. Az 1980-as években a Folkert Belzer és munkatársai által kifejlesztett oldat és annak módosításai világszerte elterjedtté váltak, és a hideg-szervkonzerválás lett az elfogadott módszer. Napjainkban a gépi perfúzió ismét a kutatások középpontjába került, és a technikai fejlődésnek köszönhetően a modern gépekkel a korábbi- 
nál lényegesen egyszerúbbé vált. A beültetést megelőző gépi perfúzió így régi-új lehetőségként ismét felkerült a palettára a májtranszplantációban. Ezáltal lehetőség nyílik a szervek minőségének javítására és a graft múködésének monitorozására a beültetés előtt. Több tanulmány megerôsíti, hogy a posztoperatív epeúti szövődmények gyakorisága csökkenthetô, valamint a grafttúlélés javítható - különösen DCD- és ECD-, de normálgraftok esetén is - gépi perfúzió alkalmazásával [51-53]. A normotermiás gépi perfúzió alkalmazásával korábban elutasított májak biztonságos transzplantációja válhat lehetôvé Nasralla és munkatársai 220 májtranszplantációt vizsgáló prospektív, randomizált tanulmánya alapján. A módszer szélesebb körben való elterjedését leginkább az anyagi lehetőségek korlátozzák. Az eljárás részleteinek kidolgozása további kutatást igényel: vizsgálják a pulzatilis és a folyamatos áramlást, a normotermiás, subnormotermiás és hypothermiás konzerválást, a perfúziós folyadékok, illetve vér alkalmazását és a perfúziós folyadékhoz adott őssejtek és farmakonok, valamint az oxigenizálás hozzáadott hasznát [54-56].

\section{Az alapkutatások szerepe a májtranszplantációban}

Az alapkutatások, valamint transzlációs medicina nélkül a májtranszplantáció fejlődése elképzelhetetlen. Az őssejtkutatások és távoli célként a szervek in vitro létrehozása, szövetek nyomtatása (tissue engineering), illetve a genetikailag módosított emlősökben létrehozott „humanizált" szervek xenotranszplantációja a lehetőségeink bővülését eredményezheti [57]. A hepatocytatranszplantáció ígéretes megoldás lehet metabolikus májbetegségekben, amit állatkísérletek és korai humán vizsgálatok alátámasztanak [58].

\section{Szervezési lehetöségek}

A nemzetközi összefogáson alapuló szervezetek a nagyobb populáció által pontosabb allokációt tesznek lehetővé. A szervezeti fejlődésnek köszönhetjük a gyümölcsöző nemzetközi együttmúködéseket, melyekben Magyarország is részesül 2013 óta Eurotransplant-tagállamként.

A magyarországi egészségügyi törvény a feltételezett beleegyezés elvét követi, ami tiltakozó nyilatkozat hiányában a holttestből a szervek és szövetek eltávolítását átültetés céljából minden különösebb korlátozás nélkül lehetôvé teszi.

$\mathrm{Az}$ agyhalott donorok számának növelése a donorkórházak aktivitásán múlik, ami jól kiépített koordinátori rendszerrel tovább javítható. A potenciális donorok felkutatása, a donorkórházak érdekeltté tétele, valamint átfogó tájékoztató kampányok szervezése hazánkban az Országos Vérellátó Szolgálat feladata. Az elmúlt években jelentôs elörelépés történt ezen a téren is. Ugyan- ilyen fontos az alapellátásban részt vevő orvosok tájékoztatása a májtranszplantáció lehetőségérôl, hogy minél több beteg hozzájuthasson ehhez a terápiás lehetôséghez. A szívmegállást követő (DCD-) donáció bevezetése az infrastrukturális feltételek biztosítását követően hazánkban is a donorok számának jelentős növekedéséhez vezetne, ennek jogi és etikai háttere azonban Magyarországon jelenleg nem áll rendelkezésre. Ennek megteremtése szakmapolitikai, illetve jogalkotói feladat.
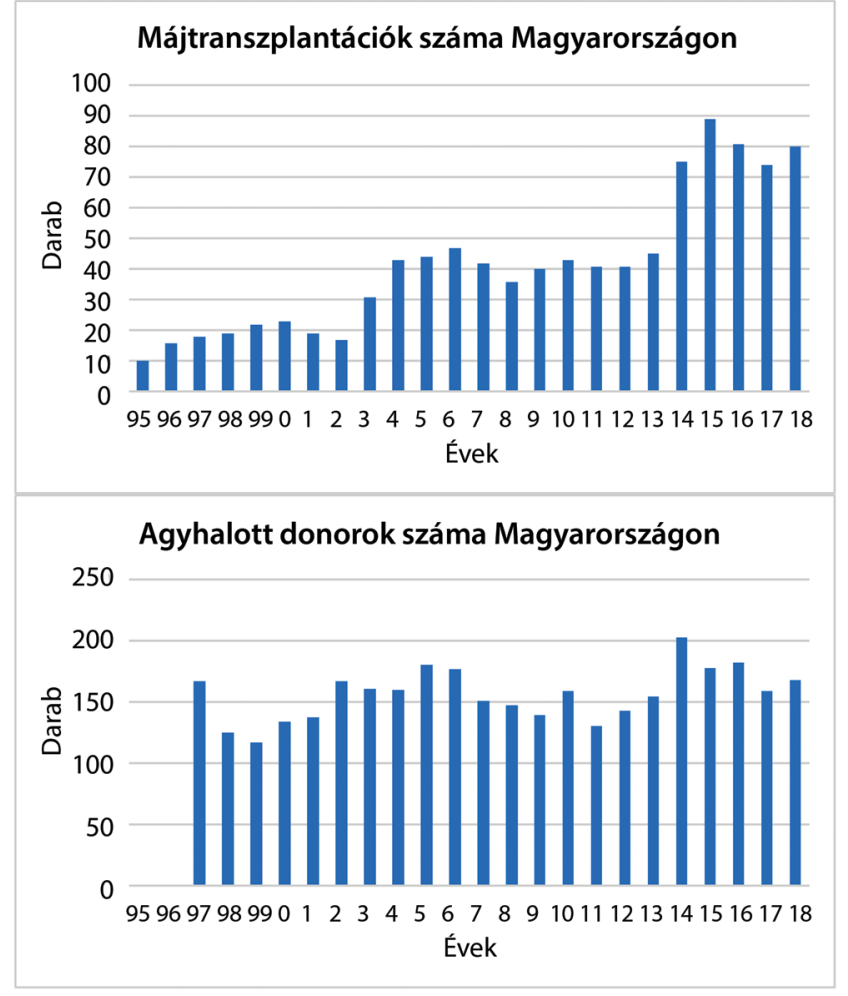

2. ábra A hazai májtranszplantációk száma az Eurotransplanthoz tör-
tént csatlakozással, valamint a kiterjesztett donorkritériumok
alkalmazásával az elmúlt években jelentősen növekedett, miköz-
ben a donorok száma nem változott érdemben. A várólistán el-
töltöött idő 0,95 és 1,12 év között volt átlagosan [61, 62]

Májtranszplantációk túlélési eredményei az Eurotransplantban és Magyarországon

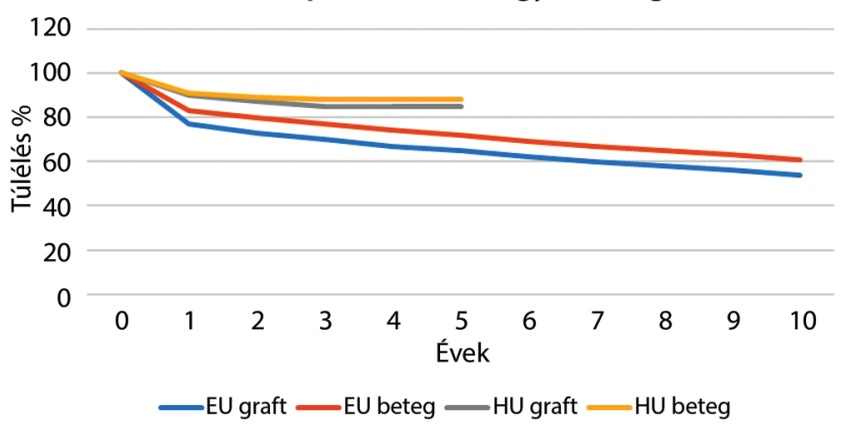

3. ábra $\mid$ A nemzetközi adatokat elérő, sőt meghaladó túlélési eredmé nyek alátámasztják a hazai májtranszplantáció sikerességét [63] 


\section{Következtetés}

Világszerte elfogadott tendencia a májtranszplantációk számának növelésére a kiterjesztett donorkritériumok alkalmazása. A kritériumok kiterjesztése azonban csak megfelelő elővigyázatossággal alkalmazható, a donor- és recipiens-rizikófaktorok egyéni elemzése, illetve személyre szabott donáció alkalmazása szükséges. Irányadó lehet a változások dinamikája, ezért szükséges a donorgondozás során a többszörös, ismételt diagnosztika. Az online döntéstámogatási rendszer kifejlesztése folyamatban van, ennek gyakorlati haszna azonban a bonyolult szempontrendszer miatt még nem tisztázott [59].

A direkt ható antivirális szereknek köszönhetően a HCV indikációjával történő transzplantációk száma csökken, és a HCV-fertőzött graftok is beültethetők DAA-terápia mellett, elsősorban HCV-fertőzött betegekbe. A máj állapotáról pontos információt sürgős májbiopsziával nyerhetünk, melynek azonban Magyarországon a legtöbb esetben az időbeli elérhetőség szab gátat. ECD-donorok esetében az eredményeket tovább javíthatja a szerv prekondicionálása és gépi perfúzió alkalmazása. Fontos megemlíteni, hogy gyermek recipiensek esetén a májtranszplantáció csak ideális feltételekkel vállalható. Az élődonoros májtranszplantáció sokszor az egyetlen esélyt jelentheti gyermekek transzplantációjára, kis súlyú recipienseknél a bal oldali májlebeny (S2-3) átültetése elegendő lehet. Felnőtteknél élődonoros jobblebeny-transzplantációt ritkán, csak indokolt esetben végzünk, egyéni mérlegelés alapján. Minden esetben az élődonor biztonságának szem előtt tartása a legfontosabb szempont.

A májtranszplantációk számának növelése új kihívásokat jelent. A sebésztechnikai innovációk új lehetőségeket adnak a kezünkbe, és biztonságosabbá teszik a mütétet a beteg számára. Az alapkutatás és a klinikum összefonódása új alternatívákat kínál, de egyúttal több lehetőséget is teremt a májtranszplantációra. A szervezési fejlődés pedig elengedhetetlen az erőforrások kiaknázásában és allokációjában.

A hazai májtranszplantációs program a kezdeti fázisból, majd főként az intenzív terápia és a haemostaseologia fejlődésével fémjelzett második korszakból egy harmadik szakaszba jutott, amikor elsősorban a megváltozott donorkritériumok körültekintő alkalmazásával a májtranszplantációk számának jelentős növelése és az eredmények folyamatos javulása volt elérhető egy időben [60] (2. ábra [61, 62] és 3. ábra [63]).

Anyagi támogatás: A közlemény megírása anyagi támogatásban nem részesült.
Szerzői munkamegosztás: W. D., T. Sz. J.: Az irodalom kutatása, a kézirat megszövegezése. M. Z.: Tervezés, az irodalom kutatása, a kézirat szerkesztése. A cikk végleges változatát mindhárom szerző elolvasta és jóváhagyta.

Érdekeltségek: A szerzőknek nincsenek érdekeltségeik.

\section{Irodalom}

[1] Gastaca M. Extended criteria donors in liver transplantation: adapting donor quality and recipient. Transplant Proc. 2009; 41: 975-979.

[2] Statistics Report Library. Eurotransplant, Leiden. Available from: statistics.eurotransplant.org [accessed: January 20, 2019].

[3] Neves DB, Rusi MB, Diaz LG, et al. Primary graft dysfunction of the liver: definitions, diagnostic criteria and risk factors. Einstein (Sao Paulo) 2016; 14: 567-572.

[4] Hoyer DP, Paul A, Gallinat A, et al. Donor information based prediction of early allograft dysfunction and outcome in liver transplantation. Liver Int. 2015; 35: 156-163.

[5] Mathé Z, Paul A, Molmenti EP, et al. Liver transplantation with donors over the expected lifespan in the model for end-staged liver disease era: is Mother Nature punishing us? Liver Int. 2011; 31: 1054-1061.

[6] Feng S, Goodrich NP, Bragg-Gresham JL, et al. Characteristics associated with liver graft failure: the concept of a donor risk index. Am J Transplant. 2006; 6: 783-790.

[7] Barshes NR, Horwitz IB, Franzini L, et al. Waitlist mortality decreases with increased use of extended criteria donor liver grafts at adult liver transplant centers. Am J Transplant. 2007; 7 : 12651270.

[8] Bolondi G, Mocchegiani F, Montalti R, et al. Predictive factors of short term outcome after liver transplantation: a review. World J Gastroenterol. 2016; 22: 5936-5949.

[9] Piotrowski D, Sączewska-Piotrowska A, Jaroszewicz J, et al. Predictive power of Model for End-Stage Liver Disease and ChildTurcotte-Pugh score for mortality in cirrhotic patients. Clin Exp Hepatol. 2018; 4: 240-246.

[10] Maluf DG, Edwards EB, Kauffman HM. Utilization of extended donor criteria liver allograft: is the elevated risk of failure independent of the model for end-stage liver disease score of the recipient? Transplantation 2006; 82: 1653-1657.

[11] Nemes B, Gelley F, Zádori G, et al. Outcome of liver transplantation based on donor graft quality and recipient status. Transplant Proc. 2010; 42: 2327-2330.

[12] Schmitz S, Lurje G, Ulmer F, et al. Loco-regional hepatocellular carcinoma treatment services as a bridge to liver transplantation. Hepatobiliary Pancreat Dis Int. 2019; 18: 228-236.

[13] Yersiz H, Shaked A, Olthoff K, et al. Correlation between donor age and the pattern of liver graft recovery after transplantation. Transplantation 1995; 60: 790-794.

[14] Verran D, Kusyk T, Painter D, et al. Clinical experience gained from the use of 120 steatotic donor livers for orthotopic liver transplantation. Liver Transpl. 2003; 9: 500-505.

[15] de Graaf EL, Kench J, Dilworth P, et al. Grade of deceased donor liver macrovesicular steatosis impacts graft and recipient outcomes more than the Donor Risk Index. J Gastroenterol Hepatol. 2012 ; 27: 540-546.

[16] Chavin KD, Taber DJ, Norcross M, et al. Safe use of highly steatotic livers by utilizing a donor/recipient clinical algorithm. Clin Transplant. 2013; 27: 732-741.

[17] Imber CJ, St Peter SD, Handa A, et al. Hepatic steatosis and its relationship to transplantation. Liver Transpl. 2002; 8: 415-423. 
[18] Berenguer M, Prieto M, San Juan F, et al. Contribution of donor age to the recent decrease in patient survival among HCV-infected liver transplant recipients. Hepatology 2002; 36: 202-210.

[19] Coordinating organ donation in Germany. German Organ Transplantation Foundation. [Koordinierung der Organspende in Deutschland. Deutsche Stiftung Organtransplantation.] Frankfurt am Main. Available from: www.dso.de [accessed: January 14, 2017] [German]

[20] Dirican A, Soyer V, Koc S, et al. Transplantation with livers from octogenarians and a nonagenarian. Transplant Proc. 2015; 47: $1323-1325$

[21] Sutherland AI, IJzermans JN, Forsythe JL, et al. Kidney and liver transplantation in the elderly. Br J Surg. 2016; 103: 62-72.

[22] Durand F, Renz JF, Alkofer B, et al. Report of the Paris consensus meeting on expanded criteria donors in liver transplantation. Liver Transpl. 2008; 14: 1694-1707.

[23] Radunz S, Paul A, Nowak K, et al. Liver transplantation using donor organs with markedly elevated liver enzymes: how far can we go? Liver Int. 2011; 31: 1021-1027.

[24] Fagiuoli S, Ravasio R, Lucà MG, et al. Management of hepatitis $\mathrm{C}$ infection before and after liver transplantation. World J Gastroenterol. $2015 ; 21$ : 4447-4456.

[25] Manzarbeitia C, Reich DJ, Ortiz JA, et al. Safe use of livers from donors with positive hepatitis B core antibody. Liver Transpl. 2002; 6: 556-561.

[26] Naggie S. Treating HCV infection: it doesn't get much better than this. Top Antivir Med. 2019; 26: 104-108.

[27] Screening, diagnosis, treatment, and follow up of hepatitis C virus related liver disease. National consensus guideline in Hungary from 26 March 2018. [Hepatitis C-vírus fertőzés szürése, diagnosztikája, antivirális terápiája, kezelés utáni gondozása. Magyar konszenzusajánlás. Érvényes: 2018. március 26-tól.] Available from: https://hepreg.hu/custom/hepreg/doc/ HCV_konszenzus_ajanlas_2018_marcius_v7.pdf [accessed: January 12, 2019]. [Hungarian]

[28] Bowring MG, Kucirka LM, Massie AB, et al. Changes in utilization and discard of hepatitis $\mathrm{C}$-infected donor livers in the recent era. Am J Transplant 2017; 17: 519-527.

[29] Nemes B, Gámán G, Polak WG, et al. Extended-criteria donors in liver transplantation. Part II: Reviewing the impact of extended-criteria donors on the complications and outcomes of liver transplantation. Expert Rev Gastroenterol Hepatol. 2016; 10: 841-859.

[30] Nemes B, Gámán G, Polak WG, et al. Extended criteria donors in liver transplantation. Part I: Reviewing the impact of determining factors. Expert Rev Gastroenterol Hepatol. 2016; 10 827-839.

[31] Cerutti E, Stratta C, Romagnoli R, et al. Bacterial- and fungalpositive cultures in organ donors: clinical impact in liver transplantation. Liver Transpl. 2006; 12: 1253-1259.

[32] Kauffman HM, McBride MA, Delmonico FL. First report of the United Network for Organ Sharing Transplant Tumor Registry: donors with a history of cancer. Transplantation 2000; 70: 1747-1751.

[33] Desai R, Neuberger J. Donor transmitted and de novo cancer after liver transplantation. World J Gastroenterol. 2014; 20: 61706179

[34] Cherqui D, Soubrane O, Husson E, et al. Laparoscopic living donor hepatectomy for liver transplantation in children. Lancet 2002; 359: 392-396.

[35] Máthé Z, Kóbori L, Görög D, et al. The first successful adult right-lobe living donor liver transplantation in Hungary. [Az első sikeres élő donoros felnőttkori jobb lebenyes májtranszplantáció Magyarországon.] Orv Hetil. 2010; 151: 3-7. [Hungarian]

[36] Doyle MB, Maynard E, Lin Y, et al. Outcomes with split liver transplantation are equivalent to those with whole organ transplantation. J Am Coll Surg. 2013; 217: 102-112.
[37] Cauley RP, Vakili K, Fullington N, et al. Deceased-donor splitliver transplantation in adult recipients: is the learning curve over? J Am Coll Surg. 2013; 217: 672-684.

[38] Merion RM, Rush SH, Dykstra DM, et al. Predicted lifetimes for adult and pediatric split liver versus adult whole liver transplant recipients. Am J Transplant. 2004; 4: 1792-1797.

[39] Chen CL, Kabiling CS, Concejero AM. Why does living donor liver transplantation flourish in Asia? Nat Rev Gastroenterol Hepatol. 2013; 10: 746-751.

[40] Fisher RA. Living donor liver transplantation: eliminating the wait for death in end-stage liver disease? Nat Rev Gastroenterol Hepatol. 2017; 14: 373-382.

[41] Newsletter Transplant. International figures on donation and transplantation, 2017. Dansk Center for Organdonation, Aarhus. Available from: http://www.transplant-observatory. org/download/6732/ [accessed: December 2018].

[42] Hoyer DP, Klein C, Kathemann S, et al. Left-lateral living related liver donation - the Essen experience. [Bal oldali élő májdonáció. Esseni tapasztalatok.] Zentralbl Chir. 2016; 141: 570-576. [German]

[43] Lauterio A, Di Sandro S, Concone G, et al. Current status and perspectives in split liver transplantation. World J Gastroenterol. 2015; 21: 11003-11015.

[44] Guidelines for the determination of death. Report of the medical consultants on the diagnosis of death to the President's Commission for the Study of Ethical Problems in Medicine and Biomedical and Behavioral Research. Conn Med. 1982; 46: 207-210.

[45] Martin K, Allen E, Johnson R. Annual report on liver transplantation. Report for 2014/2015 (1 April 2005-31 March 2015). Statistics and Clinical Studies, NHS Blood and Transplant, September 2015. Available from: http://odt.nhs.uk/pdf/organ_ specific_report_liver_2015.pdf [accessed: February 20, 2017].

[46] Selck FW, Grossman EB, Ratner LE, et al. Utilization, outcomes, and retransplantation of liver allografts from donation after cardiac death: implications for further expansion of the deceaseddonor pool. Ann Surg. 2008; 248: 599-607.

[47] de Vera ME, Lopez-Solis R, Dvorchik I, et al. Liver transplantation using donation after cardiac death donors: long-term follow-up from a single center. Am J Transplant. 2009; 9: 773-781.

[48] Grewal HP, Willingham DL, Nguyen J, et al. Liver transplantation using controlled donation after cardiac death donors: an analysis of a large single-center experience. Liver Transpl. 2009; 15: 1028-1035.

[49] Schaubel DE, Sima CS, Goodrich NP, et al. The survival benefit of deceased donor liver transplantation as a function of candidate disease severity and donor quality. Am J Transplant. 2008; 8: 419-425.

[50] Massicotte L, Thibeault L, Roy A. Classical notions of coagulation revisited in relation with blood losses, transfusion rate for 700 consecutive liver transplantations. Semin Thromb Hemost. 2015; 41: 538-546.

[51] Hoyer DP, Mathé Z, Gallinat A, et al. Controlled oxygenated rewarming of cold stored livers prior to transplantation: first clinical application of a new concept. Transplantation 2016; 100: $147-152$.

[52] Minor T, Pütter C, Gallinat A, et al. Oxygen persufflation as adjunct in liver preservation (OPAL): study protocol for a randomized controlled trial. Trials 2011; 12: 234.

[53] Weeder PD, van Rijn R, Porte RJ. Machine perfusion in liver transplantation as a tool to prevent non-anastomotic biliary strictures: rationale, current evidence and future directions. J Hepatol. 2015; 63: 265-275.

[54] Wettstein D, Hamar M, Cseprekál O, et al. Machine perfusion: new opportunities in abdominal organ transplantation. [Szervkonzerválás gépi perfúzióval: új lehetőségek a hasi szervek transzplantációjában.] Orv Hetil. 2018; 159: 1882-1890. [Hungarian] 
[55] Karangwa SA, Dutkowski P, Fontes P, et al. Machine perfusion of donor livers for transplantation: a proposal for standardized nomenclature and reporting guidelines. Am J Transplant. 2016; 16: $2932-2942$

[56] Nasralla D, Coussios CC, Mergental H, et al. Consortium for Organ Preservation in Europe. A randomized trial of normothermic preservation in liver transplantation. Nature 2018; 557(7703): 50-56.

[57] Cowan PJ, Tector AJ. The resurgence of xenotransplantation. Am J Transplant. 2017; 17: 2531-2536.

[58] Ibars EP, Cortes M, Tolosa L, et al. Hepatocyte transplantation program: lessons learned and future strategies. World J Gastroenterol. 2016; 22: 874-886.

[59] Volk ML, Goodrich N, Lai JC, et al. Decision support for organ offers in liver transplantation. Liver Transpl. 2015; 21: 784-791.

[60] Trunecka P, Gerlei Z, Lisik W, et al. Liver transplantation in Central Europe. Clin Exp Hepatol. 2016; 2: 21-26.
[61] Branger P, Samuel U. (eds.) Annual report 2017. Eurotransplant International Foundation, Leiden. Available from: http://www. eurotransplant.org $/ \mathrm{cms} /$ mediaobject.php?file=Annual+Report + 2017+HR10.pdf [accessed: January 14, 2019].

[62] Hungarian National Blood Transfusion Service. Basic data of donation and transplantation in Hungary. [Országos Vérellátó Szolgálat: Donációs-transzplantációs alapadatok.] Available from: http://www.ovsz.hu/oco/donacios-transzplantacios-alapadatok [accessed: January 14, 2019]. [Hungarian]

[63] European Liver Transplant Registry. Available from: http:// www.eltr.org/HGBUDA.html [accessed: November 17, 2018].

(Máthé Zoltán dr., e-mail: mathezol@hotmail.com)

\section{"Omne principium difficile." (Minden kezdet nehéz.)}

